\title{
ZINC INTOXICATION IN SOME FRESHWATER FISHES. I. VARIATIONS IN TISSUE ENERGY RESERVE
}

\author{
by S. A. SHAFFI
}

The effect of Zinc sulphate intoxication on tissue glycogen content of nine nutritionally important species of fish was observed after 3 hours exposure to concentrat ons ranging from 5 to $20 \mathrm{ppm}$. Liver and muscle showed an inverse relationship between the concentration of Zinc and the fall in the glycogen content. However, in brain and kidney a rise in glycogen content was observed upto $10 \mathrm{ppm}$. of Zinc intoxication. There was a marked fall in glycogen content at 15 and $20 \mathrm{ppm}$. of Zinc intoxication in brain and kidney tissues. The breakdown process of glycogen was higher in major-carps than in snake-headed and catfishes. Major-carps are less resistant to changed environmental conditions (Zinc intoxication) than the other two groups of fishes. The observed physiological changes are briefly discussed in relation to tissue hypoxia and an increase in metabolic products such as lactic acid.

\section{Intoxication par le zinc de quelques poissons d'eau douce. I. Variations de la réserve énergétique des tissus.}

Les effets de l'intoxication par le sulfate de zinc sur la teneur des tissus en giycogène ont été observés chez 9 poissons importants pour la nutrition soumis pendant 3 heures à des doses comprises entre 5 et $20 \mathrm{ppm}$. La concentration du zinc et la teneur en glycogène dans le foie et dans le muscle sont inversement proportionnelles. Cependant, dans le cerveau et les reins le glycogène augmente jusqu'à des doses de $10 \mathrm{ppm}$ de zinc; entre 15 et $20 \mathrm{ppm}$ il y a une chute marquée de la teneur en glycogène. Cette baisse du glycogène était plus forte chez Cirrhina, Labeo et Catla que chez les Ophicephalus et les poissons-chats. Les Cirrhina, Labeo et Catla sont moins résistants à l'intoxication par le zinc que les deux autres groupes de poissons. Les modifications physiologiques observées sont brièvement discutées en relation avec l'hypoxie des tissus et l'accumulation de produits de métabolisme comme l'acide lactique.

\section{INTRODUCTION}

Heavy metals have long been recognised as serious pollutants of the aquatic environment and heavy metal toxicity is often encountered in holding live fish in connection with experimental work, commercial fish farming and the management of recreational fisheries. The nature of the effect of heavy metals on fishes has been indicated to be asphyxiation due to coagulation of mucus on the gills (Westfall 1945), direct damage to gill tissue (Skidmore 1970) accumulation of metal in internal tissues (Mount 1964) and extensive damage to these tissue (Lewis \& Lewis 1971).

1. Department of Science, R.C.E., N.C.E.R.T., Bhopal, 462013. India. 
The mode of toxicity of Zinc and other heavy metals to fish has been studied in the past in relation to mortality studies. More recently Lloyd (1960), Skidmore (1970), Burton et al (1972), Sellers et al (1975), Hughes (1976) and others have suggested that cytological damage to the gills rather than mucus accumulation causes death by asphyxia. The physiological mechanism of death in these cases appears primarly to be related to a break down in gas exchange at the gills. Skidmore \& Tovell (1972) have studied the changes in several respiratory parameters of rainbow trout due to Zinc toxicity and they proposed that death in fish with gills damaged by heavy metals is probably caused by tissue hypoxia.

If we want to assume the potential harmfulness of various chemicals to the environment it is essential to know about these disturbed processes. Quite often the knowledge about the mode of action of fish toxicants and causes of death in aquatic animals is lacking in relation to biochemical parameters. In the present study the author made an attempt to know the damage to internal organs or disturbed physiological and biochemical processes in different economically important fishes exposed to different concentrations of Zinc sulphate. It seems that no body has reported the effect of Zinc intoxication in relation to tissue glycogen content on Indian tropical fishes. For the same reason the author made an attempt to know the effects of zinc sulfate intoxication on glycogen content in liver, muscle, brain and kidney tissues of 9 nutritionally important fishes (i.e., Cirrhina mrigala (Ham), Lablo rohita (Ham), Catla catla (Ham), Ophicephalus striatus Bloch, Ophicephalus punctatus Bloch, Ophicephalus marulius (Ham), Clarias batrachus (L), Heteropneustes fossilis Bloch, and Mystus seenghala (Sykes) on a comparative basis.

\section{1. - MATERIAL AND METHODS}

Healthy C. mrigala, L. rohita, C. catla, O. striatus, O. punctatus, O. marulius, $C$. batrachus, $H$. fossilis and $M$. seenghala of a particular size range $(18-20 \mathrm{~cm})$ were obtained from some selected local ponds arround Bhopal. They were acclimatized to the laboratory conditions before starting the experiment. Five fishes of each species were sacrificed for the normal estimations of glycogen in liver, muscle, kidney and brain. Equal number of each 9 species were kept for three hours in water containing 5,10,15, and $20 \mathrm{ppm}$. of Zinc sulphate. All the fishes were then removed from the medium, decapitated and dissected out for liver, muscle, brain and kidney tissues. The preparation of tissue samples, processing and expression of glycogen was elsewhere (Shaffi \& Habibulia 1977, Shaffi \& Qayyum 1978). The experiment was repeated for five times to subject the data to statistical analysis. 


\section{2. - RESULTS}

Observations made to find out the external signs of poisoning on 9 species of nutritionally important fishes exposed to 5, 10, 15, and $20 \mathrm{ppm}$. of Zinc for 3 hours. No visible symptoms of toxic reaction were seen, except the formation of a thick mucous coat on the opercular region of the fishes. The degree of mucus formation was the highiest in major carps $(C$. mrigala, L. rohita, $C$. catla) followed by snake headed fishes $(O$. striatus, $O$. punctatus, $O$. marulius $)$ and cat fishes ( $C$. batrachus, $H$. fossilis and $M$. seenghala).

TABLE I. - Changes in tissue glycogen content due to Zinc Sulphate intoxication - MAJOR CARPS.

Values ( $\mu \mathrm{gm} / \mathrm{gm}$ wet $w \mathrm{t}$. of tissue) are mean $\pm \mathrm{SE}$ of 5 replicates.

\begin{tabular}{|c|c|c|c|c|c|}
\hline $\begin{array}{c}\text { Name } \\
\text { of the Organ }\end{array}$ & CONTROL & 5 ppm & $10 \mathrm{ppm}$ & 15 ppm & $20 \mathrm{ppm}$ \\
\hline \multicolumn{6}{|c|}{ Girrhina mrigala } \\
\hline LIVER & $\begin{array}{r}4986.1 \\
\pm 306.2\end{array}$ & $\begin{array}{r}4132.1 \\
\pm 250.8\end{array}$ & $\begin{array}{r}2937.1 \\
\pm 350.9\end{array}$ & $\begin{array}{r}2095.1 \\
\pm 140.2\end{array}$ & $\begin{array}{r}650.9 \\
+\quad 99.1\end{array}$ \\
\hline MUSCLE & $\begin{array}{r}3236.7 \\
\pm 402.1\end{array}$ & $\begin{array}{r}2672.8 \\
\pm 180.9\end{array}$ & $\begin{array}{r}1872.1 \\
\pm 260.7\end{array}$ & $\begin{array}{r}1206.4 \\
\pm 120.4\end{array}$ & $\begin{array}{r}400.7 \\
\pm \quad 65.7\end{array}$ \\
\hline BRAIN & $\begin{array}{r}1250.3 \\
\pm 160.2\end{array}$ & $\begin{array}{r}1450.3 \\
\pm \quad 90.6\end{array}$ & $\begin{array}{r}1636.4 \\
\pm 150.7\end{array}$ & $\begin{array}{r}800.3 \\
\pm 95.0\end{array}$ & $\begin{array}{r}269.3 \\
+\quad 39.3\end{array}$ \\
\hline KIDNEY & $\begin{array}{r}878.1 \\
\pm \quad 50.3\end{array}$ & $\begin{array}{r}968.9 \\
\pm 105.8\end{array}$ & $\begin{array}{r}1096.8 \\
\pm \quad 76.4\end{array}$ & $\begin{array}{r}502.9 \\
+\quad 50.6\end{array}$ & $\begin{array}{r}200.8 \\
+\quad 24.3\end{array}$ \\
\hline \multicolumn{6}{|c|}{ Labeo rohita } \\
\hline LIVER & $\begin{array}{r}4492.8 \\
\pm 430.9\end{array}$ & $\begin{array}{r}3776.1 \\
\pm 310.8\end{array}$ & $\begin{array}{r}2730.1 \\
\pm 290.3\end{array}$ & $\begin{array}{r}1535.3 \\
\pm 171.0\end{array}$ & $\begin{array}{r}530.8 \\
+\quad 99.1\end{array}$ \\
\hline MUSCLE & $\begin{array}{r}3085.3 \\
\pm 196.4\end{array}$ & $\begin{array}{r}2512.1 \\
\pm 260.4\end{array}$ & $\begin{array}{r}1692.1 \\
\pm 175.3\end{array}$ & $\begin{array}{r}1055.1 \\
\pm 140.3\end{array}$ & $\begin{array}{r}310.8 \\
\pm \quad 22.7\end{array}$ \\
\hline BRAIN & $\begin{array}{r}1176.2 \\
\pm 86.2\end{array}$ & $\begin{array}{r}1325.7 \\
\pm 186.4\end{array}$ & $\begin{array}{r}1490.9 \\
\pm 150.3\end{array}$ & $\begin{array}{r}750.8 \\
\pm \quad 82.7\end{array}$ & $\begin{array}{r}215.1 \\
\pm \quad 60.1\end{array}$ \\
\hline KIDNEY & $\begin{array}{r}820.1 \\
\pm \quad 75.0\end{array}$ & $\begin{array}{r}927.1 \\
\pm 124.7\end{array}$ & $\begin{array}{r}1015.7 \\
\pm 90.8\end{array}$ & $\begin{array}{r}410.1 \\
\pm 42.1\end{array}$ & $\begin{array}{r}182,4 \\
\pm \quad 30.1\end{array}$ \\
\hline \multicolumn{6}{|c|}{ Catla catla } \\
\hline LIVER & $\begin{array}{r}4237.9 \\
\pm 190.4\end{array}$ & $\begin{array}{r}3472.8 \\
\pm 135.3\end{array}$ & $\begin{array}{r}2518.8 \\
\pm 210.7\end{array}$ & $\begin{array}{r}1378.1 \\
\pm 93.9\end{array}$ & $\begin{array}{r}427.6 \\
\pm 111.7\end{array}$ \\
\hline MUSCLE & $\begin{array}{r}2932.1 \\
\pm 230.2\end{array}$ & $\begin{array}{r}2112.9 \\
\pm 160.4\end{array}$ & $\begin{array}{r}1318.3 \\
\pm 164.3\end{array}$ & $\begin{array}{r}875.1 \\
\pm 100.1\end{array}$ & $\begin{array}{r}260.1 \\
+\quad 30.1\end{array}$ \\
\hline BRAIN & $\begin{array}{r}1025.3 \\
\pm 120.4\end{array}$ & $\begin{array}{r}1165.3 \\
\pm 128.7\end{array}$ & $\begin{array}{r}1310.7 \\
\pm 146.2\end{array}$ & $\begin{array}{r}602.1 \\
\pm \quad 60.1\end{array}$ & $\begin{array}{r}190.9 \\
+\quad 29.3\end{array}$ \\
\hline KIDNEY & $\begin{array}{r}786.2 \\
\pm 104.3\end{array}$ & $\begin{array}{r}855.1 \\
\pm 56.8\end{array}$ & $\begin{array}{r}940.1 \\
\pm 130.1\end{array}$ & $\begin{array}{r}310.9 \\
\pm \quad 36.3\end{array}$ & $\begin{array}{r}160.8 \\
\pm \quad 20.1\end{array}$ \\
\hline
\end{tabular}

Zinc intoxication has brought about a number of marked changes in the glycogen content of liver, muscle, brain and kidney in the whole 
of the 9 studied species (Tables 1-3). In liver and muscle the author always observed an inverse relationship berween the concentrations of Zinc and the fall in the total glycogen content. However, in brain and kidney the glycogen content increases up to $10 \mathrm{ppm}$. of Zinc exposer, maximum depletion of glycogen was recorder at $20 \mathrm{ppm}$. in brain and kidney tissues.

TABLE II. - Changes in tissue glycogen content due to Zinc Sulphate intoxication $\rightarrow$ SNAKE HEADED FISHES.

Values ( $\mu \mathrm{gm} / \mathrm{gm}$ wet $\mathrm{wt}$. of tissue) are mean $\pm \mathrm{SE}$ of 5 replicates.

\begin{tabular}{|c|c|c|c|c|c|}
\hline $\begin{array}{c}\text { Name: } \\
\text { of the Organ }\end{array}$ & CONTROL & $5 \mathrm{ppm}$ & $10 \mathrm{ppm}$ & $15 \mathrm{ppm}$ & $20 \mathrm{ppm}$ \\
\hline \multicolumn{6}{|c|}{ Ophicephalus striatus } \\
\hline LIVER & $\begin{array}{r}3470.2 \\
+189.8\end{array}$ & $\begin{array}{r}2890.1 \\
\pm 210.7\end{array}$ & $\begin{array}{r}2350.2 \\
\pm 143.7\end{array}$ & $\begin{array}{r}1927.1 \\
\pm 120.3\end{array}$ & $\begin{array}{r}1409.3 \\
\pm \quad 55.1\end{array}$ \\
\hline MUSCLE & $\begin{array}{r}2396.4 \\
\pm 136.4\end{array}$ & $\begin{array}{r}1936.6 \\
\pm 300.3\end{array}$ & $\begin{array}{r}1512.3 \\
\pm 120.9\end{array}$ & $\begin{array}{r}1236.7 \\
+\quad 94.9\end{array}$ & $\begin{array}{r}827.9 \\
+\quad 80.4\end{array}$ \\
\hline BRAIN & $\begin{array}{r}987.1 \\
+\quad 92.4\end{array}$ & $\begin{array}{r}1066.7 \\
\pm 150.7\end{array}$ & $\begin{array}{r}1139.4 \\
+85.8\end{array}$ & $\begin{array}{r}750.3 \\
+\quad 80.7\end{array}$ & $\begin{array}{r}360.5 \\
+\quad 42.4\end{array}$ \\
\hline KIDNEY & $\begin{array}{r}690.7 \\
+\quad 70.8\end{array}$ & $\begin{array}{r}768.8 \\
\pm 140.8\end{array}$ & $\begin{array}{r}840.5 \\
+\quad 72.1 \\
\end{array}$ & $\begin{array}{r}427.3 \\
+\quad 68.1\end{array}$ & $\begin{array}{r}250.8 \\
\pm \quad 32.7\end{array}$ \\
\hline \multicolumn{6}{|c|}{ Ophicephalus punctatus } \\
\hline LIVER & $\begin{array}{r}3296.7 \\
\pm 337.2\end{array}$ & $\begin{array}{r}2916.7 \\
\pm 193.4\end{array}$ & $\begin{array}{r}2416.3 \\
\pm 120.8\end{array}$ & $\begin{array}{r}2017.1 \\
\pm 140.7\end{array}$ & $\begin{array}{r}1270.9 \\
\pm \quad 72.0\end{array}$ \\
\hline MUSCLE & $\begin{array}{r}2285.3 \\
\pm 196.8\end{array}$ & $\begin{array}{r}1837.9 \\
\pm 160.7\end{array}$ & $\begin{array}{r}1536.8 \\
\pm 92.8\end{array}$ & $\begin{array}{r}1072.9 \\
\pm \quad 65.8\end{array}$ & $\begin{array}{r}750.8 \\
\pm \quad 35.1\end{array}$ \\
\hline BRAIN & $\begin{array}{r}905.1 \\
\pm \quad 82.1\end{array}$ & $\begin{array}{r}991.6 \\
\pm 101.7\end{array}$ & $\begin{array}{r}1084.3 \\
\pm 125.4\end{array}$ & $\begin{array}{r}680.7 \\
\pm \quad 90.8\end{array}$ & $\begin{array}{r}310.1 \\
+\quad 39.1\end{array}$ \\
\hline KIDNEY & $\begin{array}{r}636.8 \\
\pm \quad 53.4\end{array}$ & $\begin{array}{r}699.1 \\
\pm 40.1\end{array}$ & $\begin{array}{r}770.8 \\
\pm 80.1\end{array}$ & $\begin{array}{r}390.1 \\
\pm \quad 44.3\end{array}$ & $\begin{array}{r}220.1 \\
\pm 27.1\end{array}$ \\
\hline \multicolumn{6}{|c|}{ Ophicephalus marulius } \\
\hline LIVER & $\begin{array}{r}3017.8 \\
\pm 280.1\end{array}$ & $\begin{array}{r}2736.0 \\
\pm 155.4\end{array}$ & $\begin{array}{r}2190.3 \\
\pm 120.8\end{array}$ & $\begin{array}{r}1816.9 \\
\pm \quad 95.0\end{array}$ & $\begin{array}{r}1090.4 \\
\pm 101.1\end{array}$ \\
\hline MUSCLE & $\begin{array}{r}2139.9 \\
\pm 185.3\end{array}$ & $\begin{array}{r}1791.3 \\
\pm 120.3\end{array}$ & $\begin{array}{r}1375.6 \\
+89.8\end{array}$ & $\begin{array}{r}1105.6 \\
\pm \quad 80.9\end{array}$ & $\begin{array}{r}690.7 \\
+\quad 36.4\end{array}$ \\
\hline BRAIN & $\begin{array}{r}840.2 \\
\pm 96.3\end{array}$ & $\begin{array}{r}905.5 \\
\pm \quad 60.9\end{array}$ & $\begin{array}{r}975.8 \\
+\quad 70.8\end{array}$ & $\begin{array}{r}590.3 \\
\pm \quad 72.8\end{array}$ & $\begin{array}{r}250.9 \\
\pm \quad 18.3\end{array}$ \\
\hline KIDNEY & $\begin{array}{r}590.7 \\
\pm \quad 38.3\end{array}$ & $\begin{array}{r}645.4 \\
\pm 42.4\end{array}$ & $\begin{array}{r}705.1 \\
+\quad 80.1\end{array}$ & $\begin{array}{r}295.8 \\
+\quad 18.3\end{array}$ & $\begin{array}{r}170.8 \\
\pm \quad 24.3\end{array}$ \\
\hline
\end{tabular}

Among the major carps the degree of fall in the tissue glycogen content was highiest in $C$. mrigala, followed by $L$. rohita and $C$. catla. In snake headed fishes the maximum fall of glycogen was recorded in $O$. striatus followed by $O$. punctatus and $O$. martilius. In cat fishes the maximum depletion was observed in $M$. seenghala when compared to the other two fishes. In general the percentage of fall in tissue glycogen content due to Zinc intoxication in major carps is very high 
when compared to the other two groups which are known as hard fishes (They can engulf atmospheric oxygen due to their accessory respiratory organs).

Table III. - Changes in tissue glycogen content due to Zinc Sulphate intoxication - CAT FISHES.

Values $(\mu \mathrm{gm} / \mathrm{gm}$ wet $\mathrm{wt}$. of tissue) are mean $\pm \mathrm{SE}$ of 5 replicates.

\begin{tabular}{|c|c|c|c|c|c|}
\hline $\begin{array}{c}\text { Name } \\
\text { of the Organ } \\
\end{array}$ & CONTROL & $5 \mathrm{ppm}$ & $10 \mathrm{ppm}$ & 15 ppm & $20 \mathrm{ppm}$ \\
\hline \multicolumn{6}{|c|}{ Clarias batrachus } \\
\hline LIVER & $\begin{array}{r}2850.6 \\
\pm 220.1\end{array}$ & $\begin{array}{r}2416.7 \\
\pm 140.5\end{array}$ & $\begin{array}{r}2172.1 \\
\pm 120.3\end{array}$ & $\begin{array}{r}1880.7 \\
\pm 170.1\end{array}$ & $\begin{array}{r}1545.7 \\
\pm \quad 99.8\end{array}$ \\
\hline MUSCLE & $\begin{array}{r}1810.5 \\
\pm 182.3\end{array}$ & $\begin{array}{r}1527.1 \\
\pm 95.9\end{array}$ & $\begin{array}{r}1175.7 \\
\pm 115.2\end{array}$ & $\begin{array}{r}960.7 \\
\pm \quad 89.7\end{array}$ & $\begin{array}{r}760.6 \\
\pm \quad 42.3\end{array}$ \\
\hline BRAIN & $\begin{array}{r}720.8 \\
\pm 120.1\end{array}$ & $\begin{array}{r}815.7 \\
\pm \quad 60.7\end{array}$ & $\begin{array}{r}920.1 \\
\pm 82.1\end{array}$ & $\begin{array}{r}530.1 \\
\pm \quad 55.4\end{array}$ & $\begin{array}{r}405.1 \\
\pm \quad 27.0\end{array}$ \\
\hline KIDNEY & $\begin{array}{r}550.1 \\
\pm 89.3\end{array}$ & $\begin{array}{r}625.1 \\
\pm \quad 41.7\end{array}$ & $\begin{array}{r}709.9 \\
\pm 90.1\end{array}$ & $\begin{array}{r}499.7 \\
+\quad 77.0\end{array}$ & $\begin{array}{r}357.1 \\
\pm \quad 32.5\end{array}$ \\
\hline \multicolumn{6}{|c|}{ Heteropneustes fossilis } \\
\hline LIVER & $\begin{array}{r}2530.9 \\
\pm 126.3\end{array}$ & $\begin{array}{r}2016.1 \\
\pm 189.0\end{array}$ & $\begin{array}{r}1739.8 \\
\pm 127.7\end{array}$ & $\begin{array}{r}1525.1 \\
\pm 90.7\end{array}$ & $\begin{array}{r}1210.8 \\
\pm \quad 62.1\end{array}$ \\
\hline MUSCLE & $\begin{array}{r}1690.1 \\
\pm 182.4\end{array}$ & $\begin{array}{r}1236.8 \\
\pm 90.7\end{array}$ & $\begin{array}{r}990.1 \\
\pm 140.3\end{array}$ & $\begin{array}{r}706.2 \\
\pm 48.3\end{array}$ & $\begin{array}{r}535.4 \\
\pm \quad 40.1\end{array}$ \\
\hline BRAIN & $\begin{array}{r}668.3 \\
\pm \quad 39.4\end{array}$ & $\begin{array}{r}727.1 \\
\pm \quad 46.2\end{array}$ & $\begin{array}{r}805.3 \\
\pm \quad 75.8\end{array}$ & $\begin{array}{r}420.1 \\
\pm 24.2\end{array}$ & $\begin{array}{r}325.7 \\
\pm \quad 30.1\end{array}$ \\
\hline KIDNEY & $\begin{array}{r}490.1 \\
\pm 24.1\end{array}$ & $\begin{array}{r}546.7 \\
\pm \quad 30.8\end{array}$ & $\begin{array}{r}627.9 \\
\pm \quad 55.4\end{array}$ & $\begin{array}{r}330.4 \\
\pm 18.9\end{array}$ & $\begin{array}{r}275.1 \\
\pm 26.7\end{array}$ \\
\hline \multicolumn{6}{|c|}{ Mystus seenghala } \\
\hline LIVER & $\begin{array}{r}2372.5 \\
\pm 205.4\end{array}$ & $\begin{array}{r}1832.7 \\
\pm 130.7\end{array}$ & $\begin{array}{r}1336.9 \\
\pm 80.8\end{array}$ & $\begin{array}{r}1092.1 \\
\pm 101.7\end{array}$ & $\begin{array}{r}720.7 \\
\pm \quad 36.3\end{array}$ \\
\hline MUSCLE & $\begin{array}{r}1430.2 \\
\pm 105.3\end{array}$ & $\begin{array}{r}1092.6 \\
\pm 107.3\end{array}$ & $\begin{array}{r}815.3 \\
\pm \quad 72.1\end{array}$ & $\begin{array}{r}550.3 \\
\pm \quad 38.2\end{array}$ & $\begin{array}{r}350.6 \\
\pm \quad 32.3\end{array}$ \\
\hline BRAIN & $\begin{array}{r}605.9 \\
\pm \quad 46.3\end{array}$ & $\begin{array}{r}695.8 \\
\pm \quad 65.3\end{array}$ & $\begin{array}{r}770.1 \\
\pm \quad 56.2\end{array}$ & $\begin{array}{r}305.4 \\
\pm \quad 22.1\end{array}$ & $\begin{array}{r}215.4 \\
\pm \quad 42.0\end{array}$ \\
\hline KIDNEY & $\begin{array}{r}420.7 \\
+\quad 48.3 \\
\end{array}$ & $\begin{array}{r}505.9 \\
\pm \quad 49.3 \\
\end{array}$ & $\begin{array}{r}595.4 \\
\pm \quad 62.1 \\
\end{array}$ & $\begin{array}{r}290.7 \\
\pm \quad 18.1 \\
\end{array}$ & $\begin{array}{r}180.2 \\
\pm \quad 20.1\end{array}$ \\
\hline
\end{tabular}

\section{3. - DISCUSSION}

The need for oxygen is one of most pressing demands on the physiology of any organism and is aggravated in fishes by the physical properties of their respiratory medium (Hughes 1973). In recent years our knowledge of the respiratory responses of fish to conditions of hypoxia due to heavy metal intoxication has increased considerably (Burton et al 1972, Hughes 1976).

It is known that mortality due to Zinc intoxication appears prima- 
rily to be related to a break down in gas exchange at the gills and the damage caused by these heavy metals to the gills might have led to tissue hypoxia (Burton et al 1972). It may thus be surmised that any factor such as Zinc intoxication which disturbs the oxygen supply at the tissue level or $\mathrm{pH}$ equilibria in the tissue or blood may markedly affect the level of glycogen content in any tissue including liver, muscle, brain and kidney tissues.

As seen in the result section, a differential effect of Zinc sulphate on glycogen content in different tissues have been observed. The reasons for this are not clearly known at present. However, two possibilities for such differential action exist. This may be related to the distribution of Zinc in various organs (Windom et al 1973). The differential effect may also be related to the metabolic compartmentation of the tissues (Shaffi $1978 \mathrm{a}, \mathrm{b}, \mathrm{c}$ ). It appears that the Zinc sulphate intoxication causes severe anaerobic stress resulting in the break down of tissue glycogen possibly to meet the energy demands in the muscle. The initial accumulation of glycogen in the kidney and brain may be an attempt by these two tissues to conserve energy (glycogen) and therefore to restore normalcy. At a later stage however, the roxicity is so high creating an imbalance in the glycogen content of kidney and brain tissues.

The process of tissue acidosis may be very high in major carps when compared to snake headed and cat fishes. Major carps are able to get oxygen only from one source were as in snake headed and cat fishes the source of oxygen is two fold due to the presence of accessory respiratory organs, as the percentage of fall in tissue glycogen content is less when compared to major carps which are known as soft fishes. From this type of study one can assume easily that major carps are less resistant to face the changed situation than snake headed and cat fishes, as their biochemical makeup of the body may be different from snake headed and catfishes.

Tissue hypoxia due to Zinc intoxication may be one of the possible reasons for tissue glycogenolysis. When the exposure of the fishes prolongs (Zinc sulphate) the break down of glycogen is also very high, which might have led to the accumulation of metabolic products like lactic and pyruvic acid (Shaffi 1978 d).

At present it is difficult to predict the ecological significance of these acute alteration.It must also be emphasized that elimination of aquatic animals by small insidious physiological or behavioural change can be regarded as more serious than a massive fish kill, since it is less likely to be observed and corrected (Shaffi \& Qayyum 1978). Further results on tissue lactic and pyruvic acid in relation to Zinc intoxication will be communicated seperatly. The experiments regarding chronic studies of Zinc on tissue glycogen content are in progress. 
Acknowledgement. - The author is grateful to Prof. J.S. Rajput for encouragement.

\section{REFERENCES}

Burton (D. T.), Jones (A H.) \& CaIrns (J.). 1972. - Acute Zinc toxicity to rainbow trout (Salmo gairdneri) : confirmation of the hypothesis that death is related to tissue hypoxia. J. Fish. Res. Bd. Can. 29: 1463-1466.

Hughes (G. M.). 1973. - Respiratory responses to hypoxia in fish. Amer. Zool., 13, 475-489.

Hughes (G. M.). 1976. - Polluted respiratory physiology. 163-184. In « Effects of pollutants on aquatic organisms ". Vol. 2 (Edit. Lockwood, A.P.M.). Cambrigde University Press, London, New York \& Melbourne.

Lloxp (R.). 1960. - The toxicity of Zinc sulphates to rainbow trout. Ann. Appl. Biol., $48: 84-94$.

LeWIS (S. D.) \& LeWIS (W. M.). 1971. - The effect of Zinc and copper on the osmolality of blood serum of the channel cat fish, Ictalurus punctatus, Rafinesque and goldenshiner, Notemigonus crusoleucos Mitchell. Trans. Amer. Fish Soc., $100: 639-643$.

Mount (D. I.). 1964. - An autopsy technique for Zinc caused fish mortality. Trans. Amer. Fish. Soc., 93 : 174-182.

Sellers (C. M.), Heath (A. G.) \& Bass (M. L.). 1975. - The effect of sublethal concentration of copper and Zinc on ventilatory activity blood oxygen and $\mathrm{pH}$ in rainbow trout (Salmo gairdneri) Water Research, 9: 401-408.

Shaffi (S. A.) \& Habibulla (M.). 1977. - Differential distribution of glycogen, lactate and pyruvate in different regions of the adult rat brain. Ind. J. Exp. Biol., 15 : 309-310.

Shaffi (S. A.) \& QAYYUM (M. A.). 1978. - Effect of cadmium intoxication on tissue glycogen content in a fresh water cat fish $H$. fossilis Bloch. Zool. Jb. Anat., 99: $129-132$.

SHAFFI IS. A.J. 1978 a. - Biochemical compartmentation of fish tissues. 1. Brain energy reserve and metabolic products. Acta Physiol. Hunga. (in press).

Sharti (S. A.). 1978 b. - Biochemical compartmentation of fish tissues. 2. Phosphomonoesterases in brain. Curr. Sci. (in press).

Shaffi (S. A.). 1978 c. - Biochemical compartmentation of fish tissues. 3. Glycogen, lactate and pyruvate in different organs. Ind. J. Zool. (in press).

ShafFi (S. A.). 1978 d. - Zinc intoxication in some fresh water fishes. II. Variations in tissue lactic and pyruvic acids. Ind. J. Zool. (in press).

SKIDMORE (J. F.). 1970. - Respiration and osmoregulation in rainbow trout with gills damaged by Zinc sulphate. J. Exp. Biol., 52 : 481-494.

SKIdMORE (J. E.) \& Tovell (P. W. A.). 1972. - The effects of Zinc sulphate on the gills of rainbow trout. Water Research, 6: 217-230.

Westrall (B. H.). 1945. - Coagulation film anoxia in fishes. Ecology, 26 : 283-287.

Windom (H.), Stickney (R.), Smith (R.), White (D.) \& TAYloR (F.). 1973. - Arsenic, cadmium, copper, mercury and zinc in some species of North Atlantic fin fish. J. Fish. Res, Bd. Can., $30: 275-279$. 